\title{
Pandangan Dunia Pengarang untuk Pembangunan Indonesia Baru dalam Novel Layar Terkembang: Kajian Strukturalisme Genetik
}

\section{Oleh}

\author{
Achmad Yuhdi \\ Acmad_Yuhdi@gmail.com
}

\begin{abstract}
Abstrak--Muara akhir penelitian ini adalah mendeskripsikan pandangan dunia pengarang (dalam hal ini Sutan Takdir Alisyahbana) untuk pembangunan bagi Indonesia baru dalam novel Layar Terkembang. Metode yang digunakan adalah kualitatif deskriptif dengan pendekatan strukturalisme genetic menurut Lucian Goldman. Hasil penelitian ini menunjukkan bahwa pandangan dunia pengarang tentang harapan untuk pembangunan bagi Indonesia baru diserupai oleh tokoh Tuti dalam usaha mengangkat harkat kaum wanita Indonesia. Harapan itu dimulai dari perkawinan tokoh Yusuf dan Tuti. Kedua tokoh pemuda ini pada akhirnya yang memenuhi harapan pengarangnya-Sutan Takdir Alisyahbana untuk mengisi pembangunan bagi Indonesia baru.
\end{abstract}

Kata Kunci: Layar Terkembang, Sutan Takdir Alisyahbana, Strukturalisme Genetik

\section{PENDAHULUAN}

Novel Layar Terkembang merupakan karya paling fenomenal dari Sutan Takdir Alisyahbana. Teeuw (1980) menganggap bahwa Layar Terkembang merupakan karya penting ketiga di antara roman-roman sebelum perang. Sampai saat ini, penikmat sastra tidak pernah habis membahas novel tersebut. Layar Terkembang pertama kali terbit tahun 1936 oleh penerbit Balai Pustaka. Sejak saat itu sampai dengan saat ini apresiasi dan tanggapan terhadap novel Laar Terkembang terus bermunculan dari kalangan sastrawan dan akademisi.

Layar Terkembang berkisah tentang dua gadis bersaudara, Tuti dan Maria. Tuti adalah seorang guru yang bekerja dengan sungguh-sungguh sedangkan Maria adalah seorang gadis periang dan lincah. Sebagai gadis yang tergolong kaum muda, Tuti aktif pula dalam pergerakan perempuan. Ia merasa berkewajiban untuk membela kedudukan perempuan di mata laki-laki. Selain itu, ia pun berjuang melawan hatinya yang tidak lepas dari sifat perempuan yang memimpikan suami dan menjadi seorang ibu. Kedua gadis tersebut berkenalan dengan Yusuf, seorang mahasiswa kedokteran. Meskipun Yusuf pada mulanya tertarik kepada Tuti, akhirnya ia menjadi kekasih Maria. Kematian 
Maria yang disebabkan oleh penyakit TBC terasa terlalu dipaksakan sehingga terlihat hanya ingin mempertemukan cinta Yusuf dengan Tuti.

Novel Layar Terkembang menceritakan tentang perjuangan dan kegigihan wanita Indonesia dalam menggapai cita-citanya. Novel ini banyak memperkenalkan masalah-masalah para wanita Indonesia dengan benturan-benturan budaya baru menuju pemikiran moderen. Hak-hak wanita yang diremehkan oleh budaya moderen dengan kesetaraan gender banyak diungkapkan dalam novel ini dan menjadi sisi perjuangannya seperti berwawasan luas dan mandiri.

Faruk (2012) mengomentari Layar Terkembang sebagai novel yang mampu memberikan jawaban terhadap persoalan yang ditinggalkan oleh Sitti Nurbaya. Walaupun novel ini masih dalam kerangka pandangan romantisisme, akan tetapi romantisisme yang dibangun adalah romantisisme yang idealis. Novel ini berusaha meromantisasi dunia nyata sebagai dunia ideal, bukannya meromantisasi dunia lain, surga sebagai dunia ideal.

Pendapat lain tentang layar Terkembang banyak diberikan lulusan Prodi Pendidikan Bahasa dan Sastra Indonesia berdasarkan riset untuk tugas akhir mereka. Di antaranya, Lizawati (2016), meneliti tentang pendidikan karakter tokoh wanita dalam novel layar Terkembang, Somi Hata (FKIP UI, 1961) juga banyak memaparkan kepujanggaan Alisyahbana dengan cukup lengkap.

Penelitian ini akan mengulas Layar Terkembang dengan pendekatan strukturalisme genetik. Penelitian strukturalisme genetik semula dikembangkan di Perancis atas jasa Lucien Goldmann. Dia selalu menekankan latar belakang sejarah. Karya sastra, di samping memiliki unsur otonom juga tidak bisa lepas dari unsur ekstrinsik. Teks sastra sekaligus mempresentasikan kenyataan sejarah yang mengkondisikan munculnya karya sastra. Suwardi Endaswara (2011: 56) mengemukakan studi strukturalisme genetik memiliki dua kerangka besar. Pertama, hubungan antara makna suatu unsur dengan unsur lainnya dalam suatu karya sastra yang sama, dan kedua hubungan tersebut membentuk suatu jaring yang saling mengikat. Karena itu, seorang pengarang tidak mungkin mempunyai pandangan sendiri. Pada dasarnya, pengarang akan menyarankan suatu pandangan dunia secara kolektif. Pandangan tersebut juga bukan realita, melainkan sebuah refleksi yang diungkapkan secara imajinatif. 
Secara definitif strukturalisme genetik adalah analisis struktur dengan memberikan perhatian terhadap asal-usul karya dengan tetap memperhatikan unsur intrinsik dan ekstrinsik (Ratna, 2004:123). Hal itu penting untuk memperoleh keutuhan totalitas makna yang terkandung dalam karya sastra. Oleh karena itu, dapat dipahami bahwa teori Goldmann tetap mempertahankan relevansi struktur cerita dengan konteks sosial masyarakat. Hal ini sesuai dengan penegasan Faruk (2005:15) bahwa Goldmann percaya adanya homologi antara struktur karya sastra dengan struktur masyarakat, sebab keduanya merupakan produk dari aktivitas strukturasi yang sama. Teori Goldmann mencoba menyatukan analisis struktural dengan materialisme historis dan dialek-tik. Artinya, karya sastra harus dipahami sebagai suatu totalitas yang bermakna jika ditunjang oleh keterkaitan faktor eksternal seperti lingkungan sosial, budaya, ekonomi dan lain-lain. Dengan begitu, teori ini dapat mengungkap pandangan dunia kelompok sosial pengarang, yang menjadi masalah pokok dalam kajian strukturalisme genetik.

Secara sederhana, strukturalisme genetik dapat dapat diformulasikan dalam tiga langkah. Pertama, peneliti bermula dari kajian unsure intrinsik, baik secara parsial maupun dalam jalinan keseluruhan-nya. Kedua, mengkaji kehidupan sosial budaya pengarang, karena ia merupakan bagian dari komunitas tertentu. Ketiga, mengkaji latar belakang sosial dan sejarah yang turut mengkondisikan karya sastra saat diciptakan oleh pengarang (Suwardi Endraswara, 2003: 62).(Nugraheni: 159) menegaskan bahwasanya pendekatan strukturalisme genetik Lucien Goldmann terdiri dari empat aspek, yaitu makna totalitas karya sastra, pandangan dunia pengarang, struktur teks karya sastra, dan struktur sosial masyarakat yang terdapat dalam karya sastra.

Fokus dari penelitian ini adalah mendeskripsikan pandangan dunia pengarang dalam novel layar Terkembang. Pandangan dunia pengarang itu sendiri adalah komplek menyeluruh dari gagasan-gagasan, aspirasi-aspirasi, dan perasaan-perasaan yang menghubungkan secara bersama-sama anggota-anggota suatu kelompok sosial tertentu yang mempertentangkannya dengan kelompok-kelompok sosial yang lain. (Goldmann (dalam Faruk, 2012: 66)). Pandangan dunia yang ditampilkan pengarang lewat tokoh problematik (problematic hero) merupakan suatu struktur global yang bermakna. Pandangan dunia ini bukan semata-mata fakta empiris yang bersifat langsung, tetapi merupakan suatu gagasan, aspirasi dan perasaan yang dapat mempersatukan suatu kelompok sosial masyarakat. Pandangan dunia itu memperoleh bentuk konkret di dalam 
karya sastra. Pandangan dunia bukan fakta. Pandangan dunia tidak memiliki eksistensi objektif, tetapi merupakan ekspresi teoritis dari kondisi dan kepentingan suatu golongan masyarakat tertentu.

\section{METODE}

Penelitian ini menggunakan metode kualitatif. Metode kualitatif adalah prosedur penelitian yang menghasilkan data deskripsi berupa kata-kata. Data penelitian ini adalah novel Layar Terkembang. Penelitian ini menggunakan pendekatan strukturalisme genetik menurut Lucien Goldman untuk mendeskripsikan pandangan dunia pengaranng ditinjau dari harapan dan cita-cita pengarang tentang kehidupan baru bagi pembangunan untuk Indonesia dalam novel layar Terkembang. Teknik pengumpulan data yang digunakan dalam penelitian ini adalah membaca novel dan analisis dokumen. Validasi data menggunakan trianggulasi data, dan teknik analisis data menggunakan model interaktif.

\section{HASIL PENELITIAN DAN PEMBAHASAN}

\section{Analisis Tema Cerita Novel Layar Terkembang}

Pengkajian karya sastra menggunakan pendekatan strukturalisme genetiktak lepas dari pengkajian struktur karya sastra. Muniroch (2007) menjelaskan bahwa untuk memahami karya sastra secara menyeluruh, Goldmann memakai metode dialektik dengan menerapkan konsep 'keseluruhan-bagian' dan konsep 'pemahaman-penjelasan' yang hasil akhirnya adalah penemuan struktur yang dipahami sebagai pandangan dunia masyarakat. Dalam hal ini keseluruhan karya sastra dapat ditentukan dengan mengkaji unsur instrinsik karya sastra, yaitu tema.

Tema atau dasar cerita adalah pokok permasalahan yang mendominasi suatu karya sastra. Permasalahan yang merupakan titik tolak pengarang dalam menyusun cerita, sekaligus merupakan permasalahan yang ingin dipecahkan pengarang dengan karyanya itu. Adapun tema dalam novel Layar Terkembang adalah perjuangan wanita indonesia mencapai cita-citanya. Tema ini dapat terlihat dalam kutipan berikut:

"Hitam, hitam sekali penghidupan perempuan bangsa kita di masa yang silam, lebih hitam, lebih kelam dari malam yang gelap. Perempuan bukan manusia seperti laki-laki yang mempunyai pikiran dan pemandangan sendiri, yang mempunyai hidup sendiri, perempuan hanya hamba sahaya, perempuan hanya budak yang harus bekerja dan melahirkkan anak bagi laki-laki, dengan tiada 
mempunyai hak. Setinggi-tingginya ia menjadi perhiasan, menjadi permainan yang dimulia-muliakan selagi disukai, tetapi dibuang dan ditukar apbila telah kabur cahayanya, telah hilang serinya" (hal. 42).

Potongan pidato Tuti di atas menyindir kaum laki-laki dengan bentuk perlakuanya yang terkadang memposisikan kaum wanita adalah orang terpuji ketika seorang laki-laki membutuhkannya, tapi katika kebutuhannya selesai seorang laki-laki akan mencari yang lain dan akan membuangnya kembali jika sudah bosan. Lantas bagi kaum laki-laki apa arti seorang wanita kalau tak ubahnya dengan sebuah sepatu, sudah bosan atau rusak dibuang lalu beli yang lain. Jadi STA memunculkan suatu konsep baru dalam novelnya untuk merevolusi perbedaan yang sengaja dianut kaum laki-laki untuk memperlakukan wanita sebagai budak, dan laki-laki adalah rajanya. Kemudian dihadirkannyalah tokoh Tuti anak Raden Wiriatmaja dengan umur dua puluhlimatahun yang menjadi organistoris penggerak emansipasi, sehingga dalam pidatonya ada bentuk perlawanan yang dimunculkan.

Perihal percintaan, Tuti juga menunjukkan perlawanannya terhadap perasaan mencintai dengan berlebihan kepada laki-laki. Hal itu dia tunjukkan dari sikapnya menolak pertunangan dengan Supomo. Sebagai wanita yang bersikap keras hati, keputusan untuk menolak Supomo karena idealisme Tuti dalam menentukan pendamping hipup tidak terpenuhi. Tuti merasa Supomo bukan lelaki deal seperti dalam pemikirannya.

"Supomo, terhadap cintamu yang mulia dan suci itu, yang lahir dari hatimu yang lembut dan penuh kasih saying, saya tiada dapat memberikan cinta yang setara dengan itu. Hatiku kosong...kosong, maka jika kuterima cintamu itu, penerimaan itu niscaya hanya mencari pengisi kekosongan saja. Saya tidak layak mempermain-mainkan cintamu yang mulia itu, Supomo...Saya tidak dapat membrikan cinta yang kau dambakan itu kepadamu. Supomo, kepadamu kuucapkan selamat bahagia, pasti nanti akan bersua dengan orang yang dapat membalas cintamu. Meski bagaimana sedih dan meratap jiwa saya, namun sedikitpun aku tidak bermaksud mempermain-mainkan kau. Selamat bahagia, aku akan tetap menjadi saudaramu yang akan senantiasa bersedia membantumu dengan tulus ikhlas..."

Keputusan Tuti untuk menolak Supomo pada masa itu merupakan sikap yang sangat berani, karena laki-laki lain sulit untuk dapat dalam kehidupannya (terutama untuk wanita timur pada waktu itu yang layaknya disebut perawan tua). Keputusan Tuti menolak Supomo dalam kutipan surat di atas, karena keteguhan hati Tuti yang berpegang pda pendiriannya bahwa ia tidak akan menikah dengan laki-laki yang 
disebutnya "biasa" karena tidak melebihi dirinya, atau paling tidak menyamai dirinya dalam kehidupan modern.

\section{Pandangan Dunia Pengarang Melalui Perbedaan Watak Tuti dan Maria}

Selanjutnya, pandangan dunia pengarang dalam novel layar Terkembang ditunjukkan melalui dikotomi antara dunia nyata dan dunia ideal. Hal tersebut dapat dilihat dari perbedaan sifat dan karakter yang ditunjukkan kakak beradik Tuti dan Maria sejak awal penceritaan novel ini. Maria, dapat dikatakan sebagai persona yang tidak dapat lepas dari dunia nyata, sedangkan Tuti termasuk tokoh yang mengidamkan dunia ideal, bahkan Tuti selalu digambarkan mengambil jarak dari lingkungannya, tidak mudah hanyut dalam llingkungan sekitarnya karena dia mempunyai pikiran dan pandangan-pandangan pribadi.

...Antara dirinya dengan anaknya ada tentang suatu tabir yang halus dan tiada nyata kelihatan kepadanya. Terutama sekali payah ia hendak mengkaji sikap dan pendirian Tuti yang lain benar Nampak kepadanya dari Maria. Apakah gunanya ia sebagai perempuan siang-malam membuang tenaga dan waktu untuk perkumpulan, rapat di sini, rapat di sana, berpidato di sini, berpidato di sana? Apakah gunanya buku yang sebanyak itu bersusun dalam lemarinya, seperdua dari gajinya menjadi kertas saja? ...

Sejak dari awal perangai kakak beradik Tuti dan Maria sangat berbeda. Dalam kutipan di atas, tampak ayah Tuti dan Maria tidak mempunyai kekuatan memaksakan kehendaknya kepada anaknya. Dalam novel ini terlihat bahwa pengarang ingin mempertahakan sosok perempuan di masyarakat (dunia nyata) seperti Tuti (melalui dunia khayal), dimana seorang wanita tidak hanya dapat mengerjakan bagian dapur dan rumah tangga saja, melainkan bekerja dan ikut serta dalam pembangunan bangsa.

Dalam hal berorganisasi, eksistensi kaum perempuan cukup diperhitungkan. Kaum perempuan dapat menjabat sebagai pucuk pimpinan dalam sebuah perkumpulan seperti yang digambarkan oleh Sutan Takdir Alisjahbana melalui tokoh Tuti dalam novel Layar Terkembang. Bahkan, tokoh Tuti digambarkan sebagai representasi kaum perempuan yang menginginkan kebebasan berdiri sendiri menentukan nasibnya.

Kaum perempuan dalam novel Layar Terkembang sangat berpedoman dan bercermin pada kegigihan sosok Tuti. Pidato-pidato yang disampaikan oleh Tuti selalu mendapat sambutan hangat dari pendengarnya. Pidato-pidato yang disampaikannya pada forum atau rapat maupun kongres tidak jarang membakar semangat kaum perempuan untuk berjuang menuntut haknya sebagai manusia. Pada setiap berpidato, 
Tuti selalu menyinggung persoalan perempuan. Tuti selalu menggambarkan kondisi perempuan yang hitam dan kelam, bahkan lebih kelam dari malam yang gelap. Perempuan bukan manuisa seperti laki-laki yang mempunyai pikiran dan pandangan senidiri, hidup sendiri, melainkan hanya sebagai hamba sahaya. Perempuan hanya budak yang harus bekerja dan melahirkan anak bagi laki-laki yang seakan tidak mempunyai hak.

\section{Pandangan Dunia Pengarang Melalui Permasalahan Keagamaan}

Pandangan dunia pengarang selanjutnya dapat dilihat melalui aspek agama. Sutan Takdir Alisjahbana dalam novel Layar Terkembang mulai mengkritik cara beragama masyarakat kebanyakan pad masa itu. Kritikan itu diberikan kepada orangorang yang menganggap bahwa persoalan beragama/beribadah hanya milik orang tua saja. Bukan untuk orang muda.

Saya? Ah, bukankah tadi kata Tuan Parta bahwa agama itu pekerjaan orang yang telah pension? Saya pun menanti saya pension dahulu, baru akan sembahyang..."

...

Tuti yang dari tadi rupanya menahan perasaanya, segera menyambung dengan mencebil, menyatakan pandangannya, "Ya, itulah hakikat yang sebenarnya pada kebanyakan kaum priyayi atau terpelajar. Agama itu dikerjakan apabila taka da suatu apa lagi yang diharapkan dari hidup ini. Jika sudah berputus asa akan hidup, barulah mencari agama. (halaman 34)

... Pada kaum priyayi agama serta upacara yang dianggap sesuatu yang memalukan, yang tiada berani dibawa di tengah khalayak yang terhormat. Tetapi untuk melepaskannya sama sekali mereka tiada berani pula, sebab pada waktu kematian, pada waktu manusia itu perlu perhubungan akan kekuasaan yang gaib yang mengatasi kekuasaannya, ia merasa dirinya terpencil, tiada kuasa. Oleh karena kesunyian pendirian itu dipakai malu, dibuang tiada berani, maka agama mendapat kedudukan di belakang, dekat tempat bujang dalam rumah mereka yang menganggap dirinya terpelajar" hal 37.

Tiga kutipan di atas menjelaskan kepada pembaca bahwa novel Layar Terkembang tidak hanya membahas masalah emansipasi perempuan. Akan tetapi, pengarang juga mengkritik cara pandang masyarakat terhadap agama. Saat itu, agama hanya dipandang untuk masyarakat golongan bawah saja, karena kepasrahan kepada kehidupan, akhirnya mencari jalan keluar melalui agama (berdoa dan beribadah), sedangkan kaum atas (dalam hal ini priyayi jawa) menganggap seseorang priyayi yang 
menjalankan ajaran agama, beribadah sesuai perintah agama, sebagai sesuatu perbuatan yang membuat malu diri sendiri dan keluarga. Pandangan masyarakat priyayi tersebut dikritik oleh pengarang melalui berbagai pernyataan dari tokoh Tuti dan Yusuf.

Novel ini memperkenalkan masalah wanita Indonesia yang mulai merangkak pada pemikiran moderen. Kaum wanita mulai bangkit untuk memperjuangkan hakhaknya sebagai wanita berwawasan luas, serta bercita-cita mandiri. Ada beberapa bentuk yang digambarkan oleh Sutan Takdir Alisjahbana dalam novelnya, diantaranya aktivitas perempuan dalam sebuah organisasi atau perkumpulan, keterlibatan perempuan dalam dunia kerja, menuntut persamaan hak-hak perempuan dengan lakilaki sebagaimana mestinya, dan lain-lain. Hal-hal inilah yang diperjuangkan oleh Tuti sebagai pelopor emansipasi wanita pada masanya.

\section{KESIMPULAN}

Berdasarkan beberapa penjelasan yang telah disebutkan di atas, dapat disimpulkan bahwa analisis pandangan dunia pengarang novel Layar Terkembang dapat dianalisis melalui aspek: 1) tema cerita, 2) perbedaan watak tokoh Tuti dan Maria, dan 3) permasalahan pandangan masyarakat priyayi dan kaum berpendidikan dalam menjalankah ibadah dan aturan keagamaan. Sementara itu, harapan dan cita-cita pengarang tentang pembangunan bagi Indonesia baru dimulai dari bersatunya tokoh Yusuf dan Tuti. Kedua tokoh pemuda inilah yang pada akhirnya yang memenuhi harapan pengarangnya — Sutan Takdir Alisyahbana untuk mengisi pembangunan bagi Indonesia baru.

\section{DAFTAR PUSTAKA}

Alisjahbana, Sutan Takdir. 2006.Layar Terkembang.Jakarta: Balai Pustaka

Endraswara, Suwardi. 2003. Metodologi Penelitian Sastra. Yogyakarta: Pustaka Widyatama.

Faruk. 1994. Pengantar Sosiologi Sastra. Yogyakarta: Pustaka Pelajar.

2012. Novel Indonesia, Kolonialisme dan Ideologi Emansipatoris. Yogyakarta: Penerbit Ombak.

Lizawati. 2016. Pendidikan Karakter Tokoh Wanita dalam Novel Layar Terkembang Karya Sultan Takdir Alisjahbana. JURNAL PENDIDIKAN BAHASA. Vol. 5, No. 1, Juni 2016. Hal 116-127. 
Mahayana, M.S dkk. 2007. Ringkasan dan Ulasan Novel Indonesia Modern. Jakarta: Grasindo.

Muniroch, Sri. 2011. Understanding Geneting Structuralism From Its Basic Conceot. LINGUA: Jurnal Ilmu Bahasa dan Sastra. ejournal.uin-malang.ac.id2 (1) hal 3644.

Teeuw. 1980. Sastra Indonesia Modern II. Jakarta: Pustaka Jaya.. 